\title{
Conjunctival Carcinoma pTO TNM Finding V8
}

National Cancer Institute

\section{Source}

National Cancer Institute. Conjunctival Carcinoma pT O TNM Finding v8. NCI Thesaurus.

Code C140537.

Conjunctival carcinoma with no evidence of primary tumor. (from AJCC 8th Ed.) 